\title{
Microscale spatial variability of snowpack: isotopic and chemical heterogeneity of a firn pack at Qomolangma (Mount Everest), central Himalaya
}

\author{
Shiqiao ZHOU, ${ }^{1,2}$ Shichang $\mathrm{KANG}^{1}{ }^{1}$ Zhiyuan $\mathrm{CONG}^{1}$ \\ ${ }^{1}$ Institute of Tibetan Plateau Research, Chinese Academy of Sciences, 18 Shuangqing Road, Haidian District, \\ Beijing 100085, China \\ E-mail: zhoushq@itpcas.ac.cn \\ ${ }^{2}$ Institute of Plateau Meteorology, China Meteorological Administration, Chengdu 610071, China
}

\begin{abstract}
For a better understanding of snow metamorphosing processes and more precise snowice-core interpretations, it is necessary to know the extent of microscale spatial variability of isotopic and chemical distributions in a snowpack. This work presents an investigation on the horizontal heterogeneity of the isotopic and chemical distributions in a firn pack on East Rongbuk Glacier at Qomolangma (Mount Everest), central Himalaya. One pit wall of $1.2 \times 1.2 \mathrm{~m}^{2}$ at $6520 \mathrm{~m}$ a.s.l. was sampled at intervals of $10 \mathrm{~cm}$ in a matrix pattern with a total of 144 samples collected. All the samples were analyzed for $\delta^{18} \mathrm{O}$ and ionic concentrations. Small horizontal isotopic and large chemical heterogeneities were found. The averaged coefficient of variation (CV) of the twelve $10 \mathrm{~cm}$ thick layers for $\delta^{18} \mathrm{O}$ is 0.052 , and in the whole snow thickness of $120 \mathrm{~cm}$ it is 0.016 , which is in the range of analytic precision and thus indicates complete homogeneity. However, the ionic distribution shows considerable heterogeneity. The averaged $\mathrm{CV}$ values of the $10 \mathrm{~cm}$ thick layers for ionic concentrations vary in the range 0.628-1.477 depending on the ions. Based on these $\mathrm{CV}$ values, the heterogeneity sequence is: $\mathrm{Mg}^{2+}>\mathrm{Ca}^{2+}>\mathrm{K}^{+}>\mathrm{Na}^{+}>\mathrm{Cl}^{-}>\mathrm{SO}_{4}{ }^{2-}>\mathrm{PO}_{4}{ }^{3-}>\mathrm{NO}_{3}{ }^{-}>\mathrm{NH}_{4}{ }^{+}$. The averaged $\mathrm{CV}$ values for all the ions, except for $\mathrm{NH}_{4}{ }^{+}$, decrease with increasing snow thickness, although the decreasing rates and extents are different. However, the $\mathrm{CV}$ values of different ions are still large and in the range 0.183-1.116 when the snow thickness increases to $120 \mathrm{~cm}$. The heterogeneity sequence becomes: $\mathrm{K}^{+}>\mathrm{Mg}^{2+}>\mathrm{Ca}^{2+}>\mathrm{NH}_{4}{ }^{+}>\mathrm{Na}^{+}>\mathrm{Cl}^{-}>\mathrm{PO}_{4}{ }^{3-}>\mathrm{NO}_{3}{ }^{-}>\mathrm{SO}_{4}{ }^{2-}$. The $\mathrm{CV}$ average change with thickness is different for $\mathrm{NH}_{4}{ }^{+}$. From 20 to $100 \mathrm{~cm}$ it increases slightly with increasing thickness, but all the values are lower than the average of $10 \mathrm{~cm}$ thick layers.
\end{abstract}

\section{INTRODUCTION}

The method of successive snow pits is commonly used in the study of snow metamorphosing processes. In stable-isotopic studies, it is used to examine evaporation (Stichler and others, 2001), melting (Suzuki, 1993; Taylor and others, 2001; Zhou and others, 2001, 2008b; Unnikrishna and others, 2002) and refreezing (Zhou and others, 2008a) effects on the isotopic fractionation of a snowpack. In geochemical studies, this method is adopted to investigate the solute transport mechanism (Suzuki, 1982; Harrington and Bales, 1998a) and ion eluting behaviors (Brimblecome and others, 1985; Li and others, 2006) during snowmelt, and the deposition of atmospheric aerosols in snow (Ferrari and others, 2005; Zhao and others, 2006). It has also been used in hydrological and environmental studies of glacier firn at high altitudes (Fujita and others, 2006; Zhou and others, 2007). This method is based on the assumption that a snowpack is horizontally homogeneous on a microscale. However, the reliability of this assumption has never been proven, although great variability of ion concentrations between sites, which were only $1 \mathrm{~m}$ apart, was reported (Brimblecombe and others, 1985; Tsiouris and others, 1985). As slight melting could occur in summer, even at the firn surface on top of very high-elevation glaciers, it could introduce some chemical redistributions and subsequent horizontal heterogeneity, and thus leads to a misunderstanding of the snow metamorphosing processes. It could also cause incorrect interpretations of the seasonality of snow-core records, although its impact may be negligible on the ice-core records on the long-term scale. This issue has become increasingly noticeable as global warming has accelerated in recent years (Tian and others, 2006). Therefore, it is necessary to clarify the extent of spatial isotopic and chemical variability of firn pack on a microscale.

\section{METHODS}

The fieldwork was carried out at East Rongbuk Glacier on the northern slope of Qomolangma (Mount Everest) in the central Himalaya. On 21 April 2005, a firn pit was dug at a flat site at $6520 \mathrm{ma}$ a.s.I. $\left(28^{\circ} 01^{\prime} 08^{\prime \prime} \mathrm{N}, 86^{\circ} 57^{\prime} 48^{\prime \prime} \mathrm{E}\right)$ in the upper accumulation zone of the glacier. The pit wall was $1.2 \times 1.2 \mathrm{~m}^{2}$ and wholly sampled at intervals of $10 \mathrm{~cm}$ in a matrix pattern, with a total of 144 samples collected by workers wearing non-particulating suits and plastic gloves. Densities of one firn column were measured. The frozen samples were transported to a freezer at the Institute of Tibetan Plateau Research, Chinese Academy of Sciences (ITPCAS).

All the samples were subjected to isotopic and chemical analyses at ITPCAS. $\delta^{18} \mathrm{O}$ was measured using a MAT-253 spectrometer (precision $\pm 0.2 \%$ ), and ion concentrations were studied using ion chromatography. Anions $\left(\mathrm{Cl}^{-}, \mathrm{NO}_{3}{ }^{-}\right.$, $\mathrm{SO}_{4}{ }^{2-}$ and $\mathrm{PO}_{4}{ }^{3-}$ ) were analyzed by a Dionex ICS 2500 


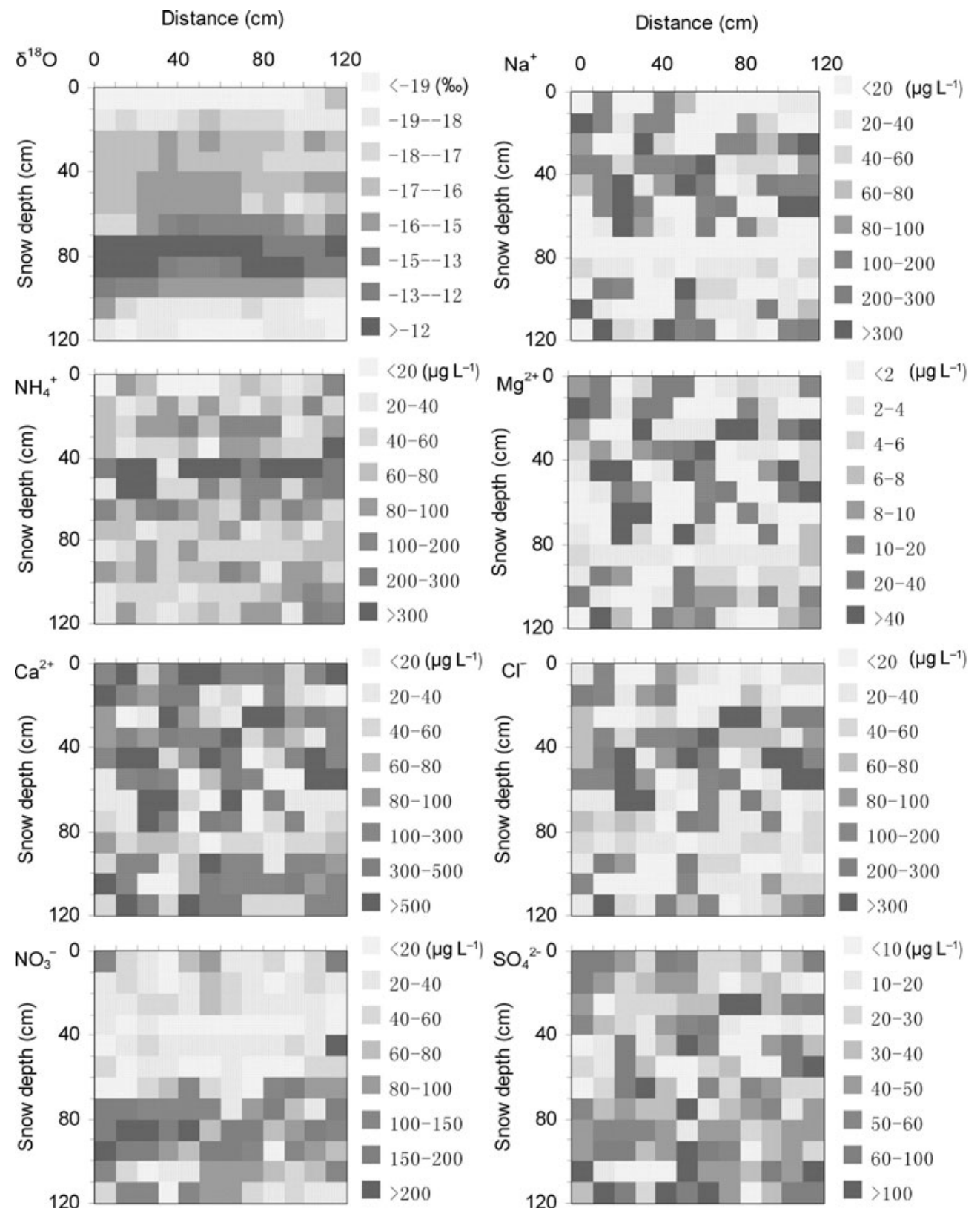

Fig. 1. Distributions of isotopic and ionic concentrations of the snow pit wall.

(RFIC) with an AS11-HC column, $500 \mu \mathrm{L}$ loop and $25 \mathrm{mM}$ $\mathrm{KOH}$ eluent. Cations $\left(\mathrm{Na}^{+}, \mathrm{K}^{+}, \mathrm{Ca}^{2+}, \mathrm{Mg}^{2+}\right.$ and $\mathrm{NH}_{4}{ }^{+}$) were analyzed by a Dionex ICS 2000 (RFIC) with a CS12A column, $200 \mu \mathrm{L}$ loop and $20 \mathrm{mM}$ methanesulfonic acid (MSA) eluent.

\section{RESULTS}

Figure 1 shows the distributions of isotopic and ionic concentrations of the snow-pit wall. Table 1 presents the statistical data of isotopic and chemical concentrations for each (12 samples) of the twelve $10 \mathrm{~cm}$ thick snow layers. It includes the lowest, highest and average values as well as the coefficient of variation ( $\mathrm{CV}$ : standard deviation divided by average value). It is seen from both Figure 1 and Table 1 that both isotopic and ionic concentrations of a layer display differences, but the extents of the differences vary. The averaged CV value of the 12 layers (CVa) for $\delta^{18} \mathrm{O}$ is 0.052 , although the differences between the lowest and highest $\delta^{18} \mathrm{O}$ values of a layer (Dm) are $1.09-4.96 \%$. This indicates that the horizontal isotopic distribution is homogeneous as a whole. However, the CVa values and Dm's for every one of the nine ions are large. The Dm's for each ion, except for $\mathrm{Ca}^{2+}$ and $\mathrm{PO}_{4}{ }^{3-}$, generally vary from several tens to several hundreds of $\mu \mathrm{g} \mathrm{L}^{-1}$. The Dm's for $\mathrm{Ca}^{2+}$, except for one layer, reach $625.04-8244.21 \mu \mathrm{gL}^{-1}$. The $\mathrm{Dm}^{\prime}$ s for $\mathrm{PO}_{4}{ }^{3-}$ are limited to several tens of $\mu \mathrm{g} \mathrm{L}^{-1}$ because of its low total load in snow. The $\mathrm{CVa}^{\prime}$ s are: $\mathrm{Cl}^{-}, 1.097 ; \mathrm{NO}_{3}{ }^{-}, 0.637 ; \mathrm{SO}_{4}{ }^{2-}$, $0.850 ; \mathrm{PO}_{4}{ }^{3-}, 0.745 ; \mathrm{Na}^{+}, 1.202 ; \mathrm{K}^{+}, 1.335 ; \mathrm{NH}_{4}{ }^{+}, 0.628$; $\mathrm{Ca}^{2+}, 1.385 ; \mathrm{Mg}^{2+}, 1.477$. These values indicate large horizontal heterogeneity of chemical distributions, although the intensity levels vary for different ions: high for $\mathrm{Ca}^{2+}$, $\mathrm{Mg}^{2+}$ and $\mathrm{K}^{+}$; intermediate for $\mathrm{Cl}^{-}$and $\mathrm{Na}^{+}$; and low for $\mathrm{NO}_{3}{ }^{-}, \mathrm{SO}_{4}{ }^{2-}, \mathrm{PO}_{4}{ }^{3-}$ and $\mathrm{NH}_{4}{ }^{+}$.

The isotopic and chemical heterogeneity/homogeneity of a snow layer would also depend on layer thickness, except for the depositional and post-depositional processes. In general, a large thickness corresponds to a low heterogeneity 


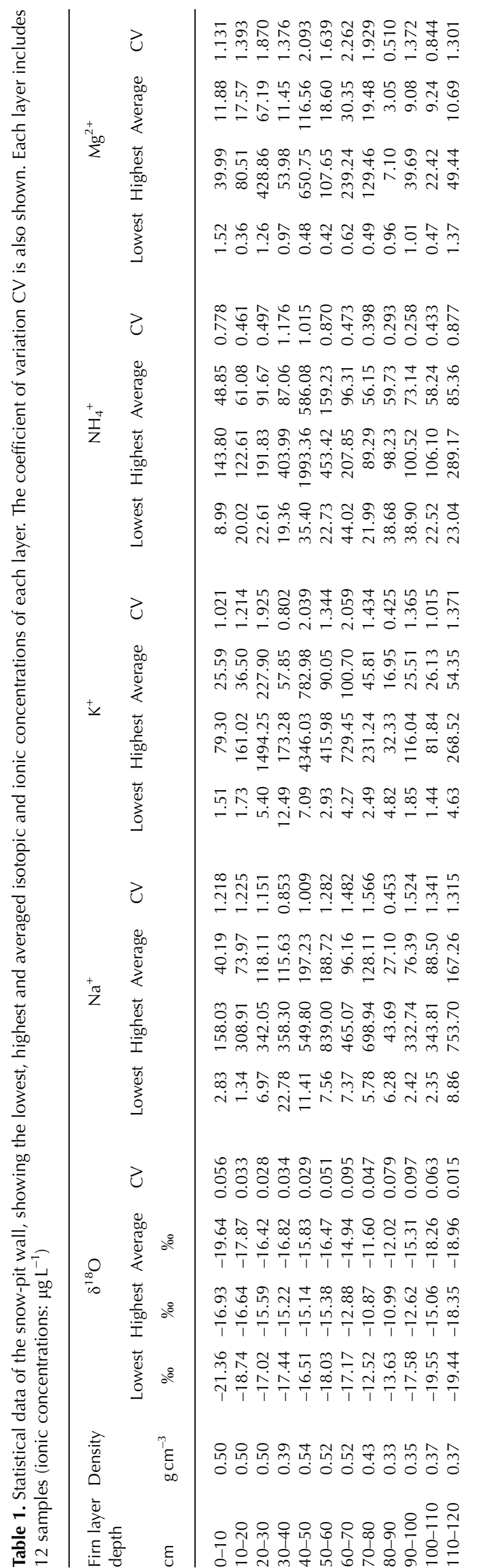

\begin{tabular}{|c|c|c|}
\hline & U & 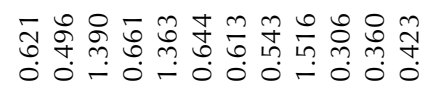 \\
\hline$m_{0}$ & 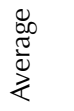 & 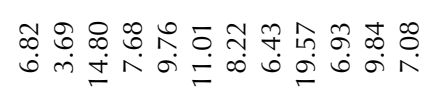 \\
\hline$\square$ & 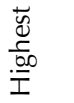 & 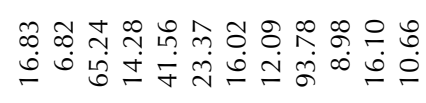 \\
\hline & 芯 & 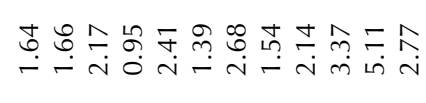 \\
\hline & 己 & 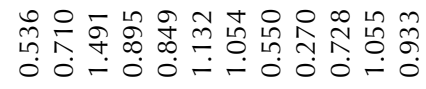 \\
\hline & 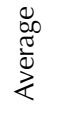 & 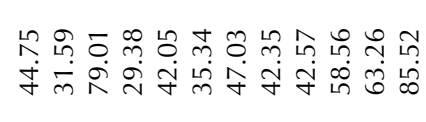 \\
\hline on & 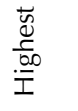 & 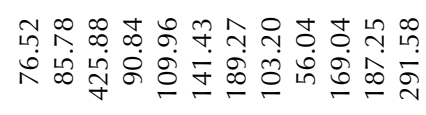 \\
\hline & 苍 & 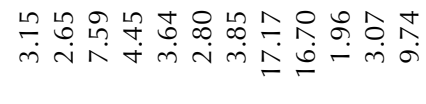 \\
\hline & U & 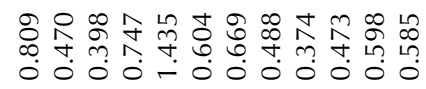 \\
\hline & 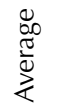 & 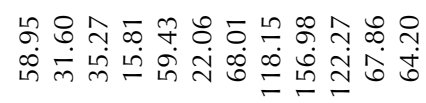 \\
\hline Z & 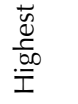 & 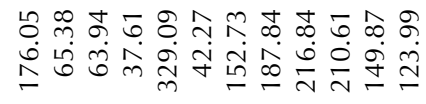 \\
\hline & 苍 & 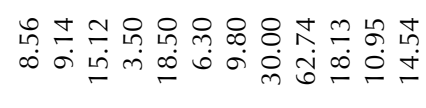 \\
\hline & 己 & 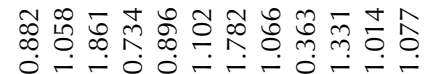 \\
\hline & 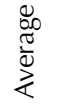 & 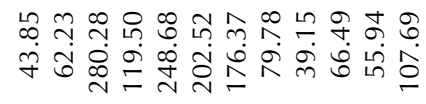 \\
\hline & $\begin{array}{l}\overrightarrow{\breve{v}} \\
\frac{6}{.00} \\
\bar{I}\end{array}$ & 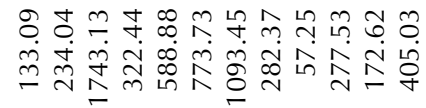 \\
\hline & 苍 & 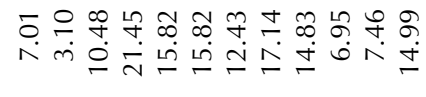 \\
\hline & 己 & 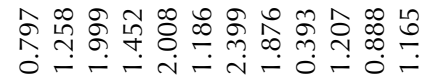 \\
\hline & 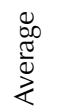 & 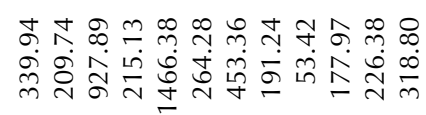 \\
\hline U & 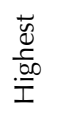 & 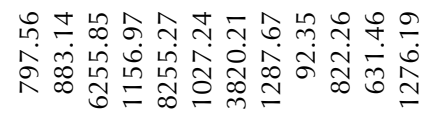 \\
\hline & 芯 & 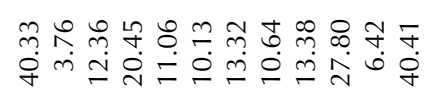 \\
\hline & ¿ & 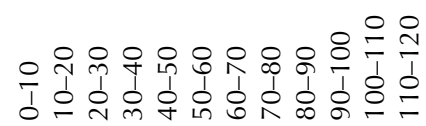 \\
\hline
\end{tabular}


Table 2. Statistical data of the snow-pit wall, showing the calculated CV ranges and averages of $20-100 \mathrm{~cm}$ snow thicknesses for $\delta^{18} \mathrm{O}$ and all the ions. The data of $10 \mathrm{~cm}$ thick layer from Table 1 are also shown for comparison (see text for details)

\begin{tabular}{|c|c|c|c|c|c|c|c|c|c|c|}
\hline \multirow{3}{*}{$\begin{array}{l}\text { Firn thickness } \\
\mathrm{cm}\end{array}$} & \multicolumn{2}{|l|}{$\delta^{18} \mathrm{O}$} & \multicolumn{2}{|l|}{$\mathrm{Na}^{+}$} & \multicolumn{2}{|l|}{$\mathrm{K}^{+}$} & \multicolumn{2}{|c|}{$\mathrm{NH}_{4}{ }^{+}$} & \multicolumn{2}{|l|}{$\mathrm{Mg}^{2+}$} \\
\hline & Range & Average & Range & Average & Range & Average & Range & Average & Range & Average \\
\hline & $\%$ & $\%$ & & & & & & & & \\
\hline 10 & $0.015-0.097$ & 0.052 & $0.453-1.566$ & 1.202 & $0.425-2.059$ & 1.335 & $0.258-1.176$ & 0.628 & $0.510-2.262$ & 1.477 \\
\hline 20 & $0.023-0.081$ & 0.045 & $0.565-1.389$ & 0.969 & $0.818-1.932$ & 1.315 & $0.191-0.926$ & 0.471 & $0.698-1.942$ & 1.395 \\
\hline 30 & $0.020-0.068$ & 0.041 & $0.467-1.288$ & 0.835 & $0.677-1.761$ & 1.291 & $0.150-0.837$ & 0.457 & $0.706-1.706$ & 1.285 \\
\hline 40 & $0.015-0.055$ & 0.036 & $0.343-1.123$ & 0.757 & $0.798-1.565$ & 1.245 & $0.132-0.765$ & 0.498 & $0.768-1.423$ & 1.195 \\
\hline 50 & $0.015-0.044$ & 0.033 & $0.333-0.931$ & 0.690 & $0.704-1.548$ & 1.237 & $0.154-0.734$ & 0.529 & $0.905-1.315$ & 1.139 \\
\hline 60 & $0.018-0.035$ & 0.030 & $0.435-0.809$ & 0.652 & $0.861-1.534$ & 1.224 & $0.183-0.699$ & 0.541 & $0.943-1.294$ & 1.082 \\
\hline 70 & $0.024-0.031$ & 0.029 & $0.438-0.738$ & 0.620 & $0.745-1.503$ & 1.217 & $0.313-0.674$ & 0.571 & $0.877-1.240$ & 1.016 \\
\hline 80 & $0.024-0.029$ & 0.026 & $0.513-0.675$ & 0.598 & $1.160-1.481$ & 1.289 & $0.571-0.665$ & 0.602 & $0.848-1.219$ & 1.008 \\
\hline 90 & $0.019-0.026$ & 0.024 & $0.505-0.604$ & 0.552 & $1.150-1.423$ & 1.227 & $0.548-0.616$ & 0.571 & $0.842-1.163$ & 0.940 \\
\hline 100 & $0.017-0.024$ & 0.021 & $0.496-0.513$ & 0.503 & $1.140-1.164$ & 1.149 & $0.534-0.560$ & 0.544 & $0.832-0.880$ & 0.849 \\
\hline 110 & $0.018-0.022$ & 0.020 & $0.451-0.473$ & 0.462 & $1.125-1.130$ & 1.127 & $0.525-0.535$ & 0.530 & $0.808-0.824$ & 0.816 \\
\hline
\end{tabular}

\begin{tabular}{|c|c|c|c|c|c|c|c|c|c|c|}
\hline \multirow{3}{*}{$\begin{array}{l}\text { Firn thickness } \\
\mathrm{cm}\end{array}$} & \multicolumn{2}{|l|}{$\mathrm{Ca}^{2+}$} & \multicolumn{2}{|l|}{$\mathrm{Cl}^{-}$} & \multicolumn{2}{|c|}{$\mathrm{NO}_{3}^{-}$} & \multicolumn{2}{|c|}{$\mathrm{SO}_{4}{ }^{2-}$} & \multicolumn{2}{|c|}{$\mathrm{PO}_{4}{ }^{3-}$} \\
\hline & Range & Average & Range & Average & Range & Average & Range & Average & Range & Average \\
\hline & & & & & & & & & & \\
\hline 10 & $0.393-2.399$ & 1.385 & $0.363-1.861$ & 1.097 & $0.374-1.435$ & 0.637 & $0.270-1.491$ & 0.850 & $0.306-1.516$ & 0.745 \\
\hline 20 & $0.692-1.893$ & 1.367 & $0.682-1.518$ & 0.949 & $0.292-1.192$ & 0.513 & $0.235-1.021$ & 0.675 & $0.292-1.663$ & 0.858 \\
\hline 30 & $0.681-1.801$ & 1.263 & $0.605-1.324$ & 0.861 & $0.221-0.877$ & 0.447 & $0.386-0.817$ & 0.588 & $0.296-1.220$ & 0.782 \\
\hline 50 & $0.619-1.282$ & 1.058 & $0.509-0.866$ & 0.608 & $0.145-0.633$ & 0.368 & $0.355-0.469$ & 0.408 & $0.416-0.746$ & 0.594 \\
\hline 60 & $0.908-1.220$ & 1.005 & $0.457-0.678$ & 0.537 & $0.134-0.547$ & 0.318 & $0.289-0.408$ & 0.356 & $0.359-0.600$ & 0.464 \\
\hline 70 & $0.753-1.140$ & 0.934 & $0.419-0.521$ & 0.474 & $0.136-0.455$ & 0.289 & $0.265-0.360$ & 0.329 & $0.341-0.458$ & 0.405 \\
\hline 80 & $0.782-1.078$ & 0.925 & $0.388-0.477$ & 0.434 & $0.223-0.397$ & 0.273 & $0.288-0.341$ & 0.305 & $0.346-0.449$ & 0.390 \\
\hline 90 & $0.776-1.016$ & 0.852 & $0.380-0.434$ & 0.401 & $0.208-0.307$ & 0.244 & $0.257-0.294$ & 0.275 & $0.288-0.386$ & 0.346 \\
\hline 100 & $0.747-0.779$ & 0.761 & $0.354-0.365$ & 0.359 & $0.212-0.256$ & 0.228 & $0.194-0.259$ & 0.227 & $0.285-0.343$ & 0.311 \\
\hline 110 & $0.701-0.732$ & 0.717 & $0.317-0.339$ & 0.328 & $0.204-0.265$ & 0.234 & $0.178-0.240$ & 0.209 & $0.286-0.299$ & 0.292 \\
\hline
\end{tabular}

and vice versa. In order to know the thickness-specific isotopic and chemical heterogeneity/homogeneity, the CVs of snow layers of different thicknesses were calculated. This was done by calculating the $n$-layer $(n: 2,3,4 \ldots 12)$ moving mass-weighted averages of isotopic and chemical concentrations using the measured $10 \mathrm{~cm}$ thick layer data, including the densities. The calculations started from the snow surface and moved downwards to the bottom layer. Table 2 lists the ranges and averages of the calculated $\mathrm{CV}$ values. It is seen from Table 2 that, except for $\mathrm{NH}_{4}{ }^{+}$and on several other occasions (e.g. the $80 \mathrm{~cm}$ thick value for $\mathrm{K}^{+}$), the $\mathrm{CV}$ averages for $\delta^{18} \mathrm{O}$ and all the ions decrease with increasing snow thickness, although the decreasing rates and extents are different. The $\mathrm{CV}$ average for $\delta^{18} \mathrm{O}$ decreases to 0.016 when the snow thickness is $120 \mathrm{~cm}$. This value falls in the range of those for measurement precision (0.010-0.017) and thus indicates that no more heterogeneity can be detected. However, the ionic concentrations still exhibit large horizontal heterogeneity in the $120 \mathrm{~cm}$ thick firn pack. The largest $\mathrm{CV}$ average is 1.116 for $\mathrm{K}^{+}$, and the lowest still reaches 0.183 for $\mathrm{SO}_{4}{ }^{2-}$ at this thickness. Differing from the other ions, the $\mathrm{CV}$ average for $\mathrm{NH}_{4}{ }^{+}$increases slightly with increasing thickness between 20 and $100 \mathrm{~cm}$, but all the values are lower than the average of the $10 \mathrm{~cm}$ thick layers.

\section{DISCUSSION}

Larger horizontal isotopic homogeneity corresponds with larger horizontal chemical heterogeneity, indicating that significant chemical redistributions occurred after snow deposition. These redistributions are most likely caused by snowmelt. Meteorological observations (Xie and others, 2006) by an automatic weather station at the same site during April to July 2005 show that the daily maximum air temperatures surpassed $0^{\circ} \mathrm{C}$, and some of them approached $10^{\circ} \mathrm{C}$ from late May onwards. In fact, even on days when the air temperature remains sub-freezing, subsurface melting can occur because the solar radiation penetrating into the firn pack combined with the low thermal conductivity of snow can lead to a subsurface temperature maximum (Koh and Jordan, 1995). In the snow pit, four ice layers were observed at depths of 49-50, 53-54, 59-60 and 88-94 cm. These ice layers indicate occurrences of snowmelt, which can introduce large microscale spatial heterogeneity, even if it is of small intensity. This is due to the fractionation process, which tells us that solute is more concentrated in the first meltwaters than in the original parent snow (Johannessen and Henriksen, 1978; Goto-Azuma, 1998). It is also due to the preferential water flow, which states that 
the liquid water in snow is not homogeneously distributed, but in different flow paths or pools (Harrington and Bales, 1998b; Feng and others, 2001). Hence, when the meltwater is refrozen in the snow, the areas of the flow paths or pools would have very high solute concentrations. Compared to the chemical impact, the effect of melting and refreezing on the isotopic composition of a snowpack is not so obvious (Zhou and others, 2008a, b), so the microscale heterogeneity is limited.

The ion-differing CV values for a given layer indicate that the extent of horizontal heterogeneity is different for different ions. This could be due to the preferential elution that ions do not fractionate into meltwaters in the same ratios at which they existed in the parent snow, or, in other words, some ions are removed at faster rates from the parent snow than others (Davies and others, 1982). However, different workers have found different elution sequences (e.g. Brimblecome and others, 1985; Li and others, 2006). Since these elution sequences were derived either by comparing the chemical composition of meltwater with that of the parent snow or by the method of successive snow pits (Goto-Azuma, 1998), this study may provide an insight into this problem from another perspective. Because of the large microscale horizontal heterogeneity and its dependence on the snow thickness, as represented by the $\mathrm{CV}$ values shown in Table 2, the chemical snowpack observations from only one snow column and at only one given thickness may produce misleading results. This could explain the discrepancies between the elution sequences observed in the different studies.

Since the snow-pit site is at an elevation where the world's highest glaciers develop, the large spatial chemical variability also suggests that great care must be taken when interpreting the chemical data of ice cores from high mountains. As the water equivalent of the firn-pack thickness of $120 \mathrm{~cm}$ is $531.5 \mathrm{~mm}$, which is more than the total precipitation of $480.8 \mathrm{~mm}$ in the year 1994 at the Pyramid Meteorological Station (5050 ma.s.l.) (Stravisi and others, 1998) in the Khumbu valley, Nepal, a few miles southwest of Qomolangma, the large spatial variability indicates great uncertainties in seasonal and even annual chemical variations. The temporal chemical variations of ice cores on seasonal and annual scales may no longer reflect the atmospheric and environmental records of snow deposition, although they could do so over longer timescales.

\section{CONCLUSION}

Microscale horizontal isotopic distribution in the firn pack is largely homogeneous. In a horizontal distance of $120 \mathrm{~cm}$, the averaged CV value of the twelve $10 \mathrm{~cm}$ thick layers for $\delta^{18} \mathrm{O}$ is 0.052 , and 0.016 in the whole $120 \mathrm{~cm}$ firn pit. The value of 0.016 is in the range of analytic precision and thus means complete homogeneity. However, the ionic distribution shows a considerable heterogeneity. The averaged $\mathrm{CV}$ values of the $10 \mathrm{~cm}$ thick layers vary in the range $0.628-1.477$, depending on the ions. Based on these $\mathrm{CV}$ values, the heterogeneity sequence is $\mathrm{Mg}^{2+}>\mathrm{Ca}^{2+}>\mathrm{K}^{+}>\mathrm{Na}^{+}>$ $\mathrm{Cl}^{-}>\mathrm{SO}_{4}{ }^{2-}>\mathrm{PO}_{4}{ }^{3-}>\mathrm{NO}_{3}{ }^{-}>\mathrm{NH}_{4}{ }^{+}$. The averaged $\mathrm{CV}$ values for all the ions, except for $\mathrm{NH}_{4}{ }^{+}$, decrease with increasing snow thickness, although the decreasing rates and extents are different. However, the $\mathrm{CV}$ values of different ions are still large and in the range 0.183-1.116 when the snow thickness increases to $120 \mathrm{~cm}$. The heterogeneity sequence becomes $\mathrm{K}^{+}>\mathrm{Mg}^{2+}>\mathrm{Ca}^{2+}>\mathrm{NH}_{4}{ }^{+}>\mathrm{Na}^{+}>\mathrm{Cl}^{-}>$ $\mathrm{PO}_{4}{ }^{3-}>\mathrm{NO}_{3}{ }^{-}>\mathrm{SO}_{4}{ }^{2-}$. The $\mathrm{CV}$ average change with thickness is different for $\mathrm{NH}_{4}{ }^{+}$. As a whole, it increases slightly with increasing thickness between 20 and $120 \mathrm{~cm}$, but all the values are lower than the average of the $10 \mathrm{~cm}$ thick layers. Great care must be taken when adopting the method of successive firn pits for temporal studies of snow chemistry or interpreting the chemical data of ice cores from high mountains.

\section{ACKNOWLEDGEMENTS}

This work was supported by the National Natural Science Foundation of China (grant No. 40671045), the Innovation Project of Chinese Academy of Sciences (grant No. KZCX2YW-317) and the National Basic Research Programme of China (grant No. 2005CB422004).

\section{REFERENCES}

Brimblecombe, P., M. Tranter, P.W. Abrahams, I. Blackwood, T.D. Davies and C.E. Vincent. 1985. Relocation and preferential elution of acidic solute through the snowpack of a small, remote, high-altitude Scottish catchment. Ann. Glaciol., 7, 141-147.

Davies, T.D., C.E. Vincent and P. Brimblecombe. 1982. Preferential elution of strong acids from a Norwegian ice cap. Nature, 300(5888), 161-163.

Feng, X., J.W. Kirchner, C.E. Renshaw, R.S. Osterhuber, B. Klaue and S. Taylor. 2001. A study of solute transport mechanisms using rare earth element tracers and artificial rainstorms on snow. Water Resour. Res., 37(5), 1425-1435.

Ferrari, C.P. and 15 others. 2005. Snow-to-air exchanges of mercury in an Arctic seasonal snow pack in Ny-Ålesund, Svalbard. Atmos. Environ., 39(39), 7633-7645.

Fujita, K. and 6 others. 2006. Thirty-year history of glacier melting in the Nepal Himalayas. J. Geophys. Res., 111(D3), D03109. (10.1029/2005JD005894.)

Goto-Azuma, K. 1998. Changes in snow pack and melt water chemistry during snowmelt. In Nakawo, M., N. Hayakawa and L.E. Goodrich, eds. Snow and ice science in hydrology. Nagoya, Nagoya University Institute for Hydrospheric-Atmospheric Sciences, 119-133.

Harrington, R.F. and R.C. Bales. 1998a. Interannual, seasonal, and spatial patterns of meltwater and solute fluxes in a seasonal snowpack. Water Resour. Res., 34(4), 823-831.

Harrington, R. and R.C. Bales. 1998b. Modeling ionic solute transport in melting snow. Water Resour. Res., 34(7), 1727-1736.

Johannessen, M. and A. Henriksen. 1978. Chemistry of snow meltwater: changes in concentration during melting. Water Resour. Res., 14(4), 615-619.

Koh, G. and R. Jordan. 1995. Sub-surface melting in a seasonal snow cover. J. Glaciol., 41(139), 474-482.

Li, Z. and 8 others. 2006. Seasonal variability of ionic concentrations in surface snow and elution processes in snow-firn packs at the PGPI site on Ürümqi glacier No. 1, eastern Tien Shan, China. Ann. Glaciol., 43, 250-256.

Stichler, W. and 6 others. 2001. Influence of sublimation on stable isotope records recovered from high-altitude glaciers in the tropical Andes. J. Geophys. Res., 106(D19), 22,613-22,620.

Stravisi, F., G.P. Verza and G. Tartari. 1998. Meteorology and climatology at high altitude in Himalaya. In Baudo, R., G. Tartari and M. Munawar, eds. Top of the world environmental research: Mount Everest - Himalayan ecosystem. Leiden, Backhuys Publishers, 101-122.

Suzuki, K. 1982. Chemical changes of snow cover by melting. Jpn J. Limnol., 43, 102-112. 
Suzuki, K. 1993. Oxygen-18 of snow meltwater and snow cover. Seppyo, J. Jpn. Soc. Snow Ice, 55(4), 335-342. [In Japanese with English summary.]

Taylor, S., X. Feng, J.W. Kirchner, R. Osterhuber, B. Klaue and C.C. Renshaw. 2001. Isotopic evolution of a seasonal snowpack and its melt. Water Resour. Res., 37(3), 759-769.

Tian, L. and 8 others. 2006. Recent rapid warming trend revealed from the isotopic record in Muztagata ice core, eastern Pamirs. J. Geophys. Res., 111(D13), D13103. (10.1029/2005JD006249.)

Tsiouris, S., C.E. Vincent, T.D. Davies and P. Brimblecombe. 1985. The elution of ions through field and laboratory snowpacks. Ann. Glaciol., 7, 196-201.

Unnikrishna, P.V., J.J. McDonnell and C.C. Kendall. 2002. Isotope variations in a Sierra Nevada snowpack and their relation to meltwater. J. Hydrol., 260(1), 38-57.

Xie, A., J. Ren, X. Qin and Y. Jiang. 2006. Meteorological features at $6523 \mathrm{~m}$ a.s.I. on the north slope of Mt Qomolangma from May 1 to July 22 in 2005. J. Glaciol. Geocryol., 28(6), 909-917. [In Chinese with English summary.]

Zhao, Z., Z. Li, R. Edwards, F. Wang, H. Li and Y. Zhu. 2006. Atmosphere-to-snow-to-firn transfer of $\mathrm{NO}_{3}{ }^{-}$on Ürümqi glacier No. 1, eastern Tien Shan, China. Ann. Glaciol., 43, 239-244.

Zhou, S., M. Nakawo, S. Hashimoto, A. Sakai, H. Narita and N. Ishikawa. 2001. Isotopic fractionation and profile evolution of a melting snowcover. Sci. China E, 44(Suppl. 1), 35-40.

Zhou, S., M. Nakawo, A. Sakai, Y. Matsuda, K. Duan and J. Pu. 2007. Water isotope variations in the snow pack and summer precipitation at July 1 Glacier, Qilian Mountains in northwest China. Chinese Sci. Bull., 52(21), 2963-2972.

Zhou, S., M. Nakawo, S. Hashimoto and A. Sakai. 2008a. The effect of refreezing on the isotopic composition of melting snowpack. Hydrol. Process., 22(6), 873-882.

Zhou, S., M. Nakawo, S. Hashimoto and A. Sakai. 2008b. Preferential exchange rate effect of isotopic fractionation in a melting snowpack. Hydrol. Process., 22(18), 3734-3740. 